\title{
BACTERIAL UROPATHOGENS IN URINARY TRACT INFECTION AND ANTIBIOTIC SUSCEPTIBILITY PATTERN IN JIMMA UNIVERSITY SPECIALIZED HOSPITAL, SOUTHWEST ETHIOPIA
}

\author{
Getenet Beyene $^{* 1}$, Wondewosen Tsegaye ${ }^{1}$
}

\section{ABSTRACT}

BACKGROUND: Urinary tract infection (UTI) is one of the most common bacterial infections encountered by clinicians in developing countries. Area-specific monitoring studies aimed to gain knowledge about the type of pathogens responsible for urinary tract infections and their resistance patterns may help the clinician to choose the correct empirical treatment. Therefore, the aim of this study was to determine the type and antibiotic resistance pattern of the urinary pathogens isolated from patients attending Jimma University Specialized Hospital from April to June 2010.

METHODS: A hospital based cross sectional stud was conducted and urine samples were collected using the mid-stream "clean catch" method from 228 clinically-suspected cases of urinary tract infections and tested bacteriologically using standard procedures. Antimicrobial susceptibility test was performed for the isolated pathogens using Kirby-Bauer disk diffusion method according to Clinical and Laboratory Standards Institute guidelines.

RESULTS: - Significant bacteria were detected from $9.2 \%$ of the total patients. The most common pathogens isolated were Escherichia coli (33.3\%), Klebsiella pneumoniae (19\%) and S. saprophyticus (14.3\%). E. coli and Klebsiella pneumoniae showed the highest percentage of resistance to ampicillin and amoxacillin (100\%) however, all isolates of $\mathrm{E}$. coli and $\mathrm{K}$. pneumoniae were susceptible to ciprofloxacin. S. saprophyticus and $S$. aureus were resistant to ampicillin (100\%) and amoxicillin (66.7\%). For all UTI isolates, least resistance was observed against drugs such as ceftriaxone, gentamycin and chloramphenicol.

CONCLUSION: - This study finding showed that $E$. coli isolates were the predominant pathogens and the presence of bacterial isolates with very high resistance to the commonly prescribed drugs that in turn leaves the clinicians with very few alternative options of drugs for the treatment of UTIs. As drug resistance among bacterial pathogens is an evolving process, routine surveillance and monitoring studies should be conducted to provide physicians knowledge on the updated and most effective empirical treatment of UTIs.

KEYWORDS: Urinary tract infection, antimicrobial resistance, Jimma, Ethiopia

\section{INTRODUCTION}

Among the most common infectious diseases, urinary tract infections (UTIs) are a commonly encountered diseases by clinicians in developing countries with an estimated annual global incidence of at least 250 million $(1,2)$. UTIs refer to the presence of microbial pathogens within the urinary tract and it is usually classified by the infection site:-bladder [cystitis], kidney [pyelonephritis], or urine [bacteriuria]) and also can be asymptomatic or symptomatic, UTIs that occur in a normal genitourinary tract with no prior

\footnotetext{
${ }^{1}$ Department of Laboratory Sciences and Pathology, College of Public Health and Medical Sciences, Jimma University

*Corresponding Author: email-rgetenet@yahoo.com
} 
instrumentation are considered as "uncomplicated," whereas "complicated" infections are diagnosed in genitourinary tracts that have structural or functional abnormalities, including instrumentation such as indwelling urethral catheters, and are frequently asymptomatic $(3,4)$. It has been estimated that globally symptomatic UTIs result in as many as 7 million visits to outpatient clinics, 1 million visits to emergency departments, and 100,000 hospitalizations annually (5).

Many different microorganisms can cause UTIs though the most common pathogens causing the simple ones in the community are Escherichia coli and other Enterobacteriacae, which accounts approximately $75 \%$ of the isolates. In complicated urinary tract infections and hospitalized patients, organisms such as Enterococcus faecalis and highly resistant Gram-negative rods including Pseudomonas spp. are comparatively more common. The relative frequency of the pathogens varies depending upon age, sex, catheterization, and hospitalization (6).

Treatment of UTIs cases is often started empirically and therapy is based on information determined from the antimicrobial resistance pattern of the urinary pathogens (5). However, a large proportion of uncontrolled antibiotic usage has contributed to the emergence of resistant bacterial infections (7-10). As a result, the prevalence of antimicrobial resistance among urinary pathogens has been increasing worldwide. Associated resistance, i.e. the fact that a bacterium resistant to one antibiotic is often much more likely to be resistant to other antibiotics, drastically decreases our chances of getting a second empirical attempt right (11). Resistance rates to the most common prescribed drugs used in the treatment of UTIs vary considerably in different areas world-wide. The estimation of local etiology and susceptibility profile could support the most effective empirical treatment (12). Therefore, investigating epidemiology of UTIs (prevalence, risk factors, bacterial isolates and antibiotic sensitivity) is fundamental for care givers and health planners to guide the expected interventions. Thus, the aim of this study was to determine bacterial etiologic agent of uropathogens and evaluate their in vitro susceptibility pattern to commonly used antimicrobial agents.

\section{MATERIALS AND METHODS}

The study was performed on UTI cases attending Jimma University Specialized Hospital from April to June 2010. A total of 228 clean catch midstream urine samples were collected in a wide mouth sterile container from the study subjects who have not received antimicrobials within the previous fifteen days. Then the bacterial uropathogens were isolated and tested for antimicrobial drug resistance pattern.

Bacterial isolation and identification procedures: Isolation of uropathogens was performed by a surface streak procedure on both blood and MacConkey agar (Oxoid Ltd. Bashingstore Hampaire, UK) using calibrated loops for semiquantitative method and incubated aerobically at $37{ }^{0} \mathrm{C}$ for 24 hours, and those cultures which becomes negative at the end of $24 \mathrm{hrs}$ incubations were further incubated for 48 hours. A specimen was considered positive for UTI if a single organism was cultured at a concentration of $\geq 10^{5}$ $\mathrm{cfu} / \mathrm{ml}$. Bacterial identification was made using biochemical tests, namely indole, citrate, oxidase, $\mathrm{H} 2 \mathrm{~S}$ production, lysine decarboxylase, lactose fermentation, urea hydrolysis, gas production, catalase, coagulase, manitol fermentation and novobiocin susceptibility test (7).

Susceptibility testing: Antimicrobial susceptibility of isolates was tested for all 21 bacterial uropathogens by the disk diffusion according to Clinical Laboratory Standards Institute (CLSI) guide lines (13).The antibiotic discs and their concentrations were: Clindamycin (CL, $2 \mu \mathrm{g})$ Amoxicillin (AML, 10 $\mu \mathrm{g}$ ), Ampicillin (AMP, $10 \mu \mathrm{g})$, Tetracycline (TE, 30 $\mu \mathrm{g}$ ), Chloramphenicol

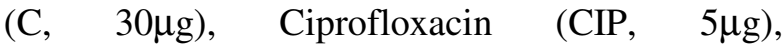
Trimethoprim+Sulphamethazole (SXT, 25 $\mu \mathrm{g}$ ) ,

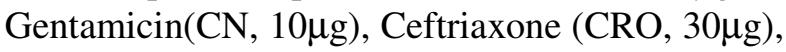

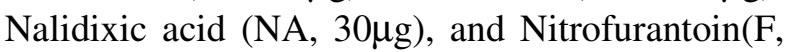
$300 \mu \mathrm{g})$. All the antimicrobials used for the study were obtained from Oxoid Ltd. Bashingstore Hampaire, UK. A standard inoculum adjusted to 0.5 McFarland was swabbed on to Muller- Hinton 
agar (Oxoid Ltd. Bashingstore Hampaire, UK); antibiotic disc were dispensed after drying the plate for $3-5 \mathrm{~min}$ and incubated at $37^{\circ} \mathrm{C}$ for 24 hours.

The reference strains used as control were $E$. coli (ATCC 25922), S. aureus (ATCC25923) and $P$. aeruginosa (ATTC 27853).

Data were entered and analyzed using SPSS version 12.0.1 windows. Discrete variables were expressed as percentages and proportions were compared using the Chi-square test. Statistical significance difference were considered at value of $\mathrm{p}<0.05$.

Ethical clearance was obtained prior to data collection from the College of Public and Health
Sciences Ethical Review committee and all the study subjects were enrolled after written informed consent was obtained.

\section{RESULTS}

The demographic characteristic of the study subjects showed that, the majority of them were (58.3\%) living in urban area and 212(93\%) were outpatients. Significant proportions were $(64.9 \%)$ female, $122(53.5 \%)$ in the age categories of 19 to 39 years, $182(80.2 \%)$ married and $139(62.6 \%)$ were either illiterate or read and write. The age range of the patients was between 15-82 years with a median of 37.1 (Table.1).

Table 1. Characteristics of study participants Jimma University Specialized Hospital from April to June 2010.

\begin{tabular}{lll}
\hline Variables & Number & Percentage \\
\hline Location & 133 & 58.3 \\
Urban & 95 & 41.7 \\
Rural & & \\
Sex & 80 & 35.1 \\
$\quad$ Male & 148 & 64.9 \\
$\quad$ Female & & \\
Age Categories & 22 & 9.6 \\
$\quad$ Less or equal to 18 years & 122 & 53.5 \\
19 to 39 years & 59 & 25.9 \\
40 to 59 years & 25 & 11.0 \\
Greater than or equal to 60 years & & \\
Educational level & 64 & 28.1 \\
Illiterate & 81 & 36.5 \\
Write and read only & 42 & 18.4 \\
Up to 8 grade complete & 33 & 14.5 \\
Up to 12 grade complete & 8 & 3.5 \\
$\quad$ University level & & \\
Marital status & 42 & 18.5 \\
Single & 182 & 80.2 \\
Married & 2 & 0.9 \\
Divorced & 2 & 0.8 \\
Widowed & & \\
\hline
\end{tabular}

Out of 228 cultured urine specimens, significant bacteriuria were detected only on $21(9.2 \%)$ of the cases. As it is shown in Table 2, $50 \%$ of the isolates were $E$. coli and $K$ pneumoniae while other gram negatives were found in small in number. On the other hand the isolated Gram positive bacteria were $S$. aureus and $S$. saprophytics with proportion of $1(4.8 \%)$ and $3(14.3 \%)$, respectively. The gram positive and gram negative bacterial proportion was $4(19.1 \%)$ and $17(80.9 \%)$, respectively. 
Table 2. Frequency of bacterial uropathogens isolated from UTI suspected patients, Jimma University Specialized Hospital, April to June 2010.

\begin{tabular}{lll}
\hline Isolates & Number & Percentage \\
\hline Citrobacter species & 2 & 9.5 \\
E. coli & 7 & 33.3 \\
Entrobacter cloacae & 2 & 9.5 \\
K. pneumoniae & 4 & 19.0 \\
P. mirabilis & 1 & 4.8 \\
Providencia stuart & 1 & 4.8 \\
S. aureus & 1 & 4.8 \\
S. saprophyticus & 3 & 14.3 \\
Tolal & 21 & 100 \\
\hline
\end{tabular}

There was no statistically significant variation observed $(\mathrm{P}>0.5)$ for variables such as being inpatient or outpatient; area of residence, sex, pregnancy and stage of pregnancy, age groups and other factors except the history of catheterization $\left(\chi^{2}=10.3 ; \mathrm{P}=0.001\right)$.

Bacterial uropathogen isolates from patients with UTIs revealed the presence of high levels of single and multiple antimicrobial resistances against commonly prescribed drugs (Table 3 ). E. coli which is the predominant cause of UTI, showed high percentage of resistance to ampicillin and amoxacillin (100\%), and low resistance to ciprofloxacin (14.3\%). Klebsiella spp which is the second most prevalent pathogen of UTI displayed a similar resistance pattern as of E.coli and showed hundred percent resistant to ampicillin and amoxicillin; however, all isolates were susceptible to ciprofloxacin and all others gram negative isolates were similarly resistant to ampicillin and amoxicillin as to that of E. coli and K. pneumonia.

Table 3. Resistance pattern of bacterial isolate from urine culture Jimma specialized Hospital from April to June 2010

\begin{tabular}{|c|c|c|c|c|c|c|c|c|c|c|c|}
\hline \multirow[b]{2}{*}{ Organisms } & \multicolumn{11}{|c|}{ Number of strains (\%) resistant to } \\
\hline & AMP & AML & $\mathrm{CL}$ & $\mathrm{C}$ & NA & CIP & $\mathrm{CN}$ & $\mathrm{CRO}$ & $\mathrm{TE}$ & $\mathrm{F}$ & SXT \\
\hline $\begin{array}{l}\text { E. coli } \\
(\mathrm{n}=7)\end{array}$ & $\begin{array}{l}7 \\
(100)\end{array}$ & $\begin{array}{l}7 \\
(100)\end{array}$ & $\begin{array}{l}2 \\
(28.6)\end{array}$ & 0 & 0 & $\begin{array}{l}1 \\
(14.3)\end{array}$ & 0 & 0 & $\begin{array}{l}2 \\
(28.6)\end{array}$ & 0 & $\begin{array}{l}2 \\
(28.6)\end{array}$ \\
\hline $\begin{array}{l}\text { K. pneumonia } \\
(\mathrm{n}=4)\end{array}$ & $\begin{array}{l}4 \\
(100)\end{array}$ & $\begin{array}{l}4 \\
(100)\end{array}$ & $\begin{array}{l}4 \\
(100)\end{array}$ & $\begin{array}{l}2 \\
(50)\end{array}$ & 0 & 0 & $\begin{array}{l}1 \\
(25)\end{array}$ & $\begin{array}{l}1 \\
(25)\end{array}$ & $\begin{array}{l}2 \\
(50)\end{array}$ & $\begin{array}{l}2 \\
(50)\end{array}$ & $\begin{array}{l}3 \\
(75)\end{array}$ \\
\hline $\begin{array}{l}S . \\
\text { saprophyticus } \\
(n=3)\end{array}$ & $\begin{array}{l}2 \\
(66.7)\end{array}$ & $\begin{array}{l}2 \\
(66.7)\end{array}$ & 0 & 0 & 2 & 0 & 0 & 0 & 0 & 0 & 0 \\
\hline $\begin{array}{l}\text { Enterobacter } \\
\text { species } \\
(\mathrm{n}=2)\end{array}$ & $\begin{array}{l}2 \\
(100)\end{array}$ & $\begin{array}{l}2 \\
(100)\end{array}$ & $\begin{array}{l}2 \\
(100)\end{array}$ & 0 & nd & 0 & 0 & 0 & 1 & nd & 0 \\
\hline $\begin{array}{l}\text { Citrobacter } \\
\text { species }(n=2)\end{array}$ & $\begin{array}{l}2 \\
(100)\end{array}$ & $\begin{array}{l}2 \\
(100)\end{array}$ & $\begin{array}{l}2 \\
(100)\end{array}$ & $\begin{array}{l}1 \\
(50)\end{array}$ & $\begin{array}{l}1 \\
(50)\end{array}$ & $\begin{array}{l}1 \\
(50)\end{array}$ & 0 & $\begin{array}{l}1 \\
(50)\end{array}$ & $\begin{array}{l}1 \\
(50)\end{array}$ & 0 & $\begin{array}{l}2 \\
(100)\end{array}$ \\
\hline $\begin{array}{l}P . \quad \text { mirabilis } \\
(n=1)\end{array}$ & $\begin{array}{l}1 \\
(100)\end{array}$ & $\begin{array}{l}1 \\
(100)\end{array}$ & $\begin{array}{l}1 \\
(100)\end{array}$ & 0 & nd & 0 & 0 & 0 & $\begin{array}{l}1 \\
(100)\end{array}$ & nd & 0 \\
\hline $\begin{array}{l}\text { Providentia } \\
\text { species }(n=1)\end{array}$ & $\begin{array}{l}1 \\
(100)\end{array}$ & $\begin{array}{l}1 \\
(100)\end{array}$ & 0 & 0 & $\mathrm{Nd}$ & 0 & 0 & 0 & 0 & nd & 0 \\
\hline $\begin{array}{l}\text { S.aureu } \\
(n=1)\end{array}$ & 0 & $\begin{array}{l}1 \\
(100)\end{array}$ & $\begin{array}{l}1 \\
(100)\end{array}$ & $\begin{array}{l}1 \\
(100)\end{array}$ & $\begin{array}{l}1 \\
(100)\end{array}$ & $\begin{array}{l}1 \\
(100)\end{array}$ & 0 & $\begin{array}{l}1 \\
(100)\end{array}$ & $\begin{array}{l}1 \\
(100)\end{array}$ & 0 & $\begin{array}{l}1 \\
(100)\end{array}$ \\
\hline
\end{tabular}

CL: Clindamycin; AML: Amoxacillin; AMP: Ampicillin; C: Choramphenicol; NA: Nalidixic acid; CIP: Ciprofloxacin; CN: Gentamycin; CRO: Ceftriaxone; TE: Tetracycline; F: Nitrofurantoin; SXT: Trimethoprim-sulphamethoxazole, nd; Not done Some of the \# of resistance to respective organisms is 1 and is concluded 100\% ressistance but it was not repeated at different time, was done with same size.

In this study, staphylococci were responsible for about $18.1 \%$ of UTIs cases; among these, $S$. saprophyticus was the most common species isolated. S. saprophyticus and Staphylococcus aureus were resistant to ampicillin and amoxacillin in $100 \%$ and $66.77 \%$ of the cases, 
respectively. However, nitrofurantion resistance was detected only in $2 \mathrm{~K}$. pneumoniae isolates, and to all isolates least resistance was observed for drugs such as ceftriaxone gentamycin and chloramphenicol.

\section{DISCUSSION}

Bacterial infection of the urinary tract is one of the common causes for seeking medical attention in the community, (14). Effective management of patients suffering from bacterial UTIs commonly relays on the identification of the type of organisms that caused the disease and the selection of an effective antibiotic agent to the organism in question (15).

In this study, the isolation rate of bacteria from urine was $9.2 \%$ which is comparatively lower than reports within the country and other part of the world (14, 16-19), this might have been either due to sample size variation or the studies might have been based on retrospective survey. However, this finding is in line with studies done in Addis Ababa (20) and one from Iran which had a rate of $13.2 \%$ (12).

Escherichia coli (E. coli) is the major aetiological agent in causing UTI, which accounts for up to $90 \%$ of cases (21). In this study, the most frequent uropathogens were Gram negatives which made up $80.9 \%$ of all the isolates. E. coli is by far the most common bacteria isolated from urine samples in both outpatients and inpatients of both sexes, and this finding is in agreement with others finding too $(12,16,19,22)$. In contrary to others study findings where the second reported isolates was Staphylococcus species $(16,20,22$, 23 ), in this study it was $K$. pneumoniae which is in agreement with the findings of Khameneh et al (24) and Chin et al (25).

Resistance to antimicrobial agents has been noted since the first use of these agents and is an increasing world-wide problem (6). This study revealed that a higher prevalence rate of resistance to the commonly prescribed antibiotic agent. The finding that $100 \%$ of E. coli and K. pneumoniae isolates were resistant to Amoxicillin and Ampicillin is of great importance and implies that these antibiotics cannot be used as empirical therapy for urinary tract infection particularly in the study area. On the other hand very low levels of resistance were detected to antibiotics such as ceftriaxone, nitrofurantoin and gentamycin and a comparable rate of sensitivity has been reported for these drugs in previous studies done in Ethiopia (16, 17, 20, 26, 27), in Kosovo (19), in Iran (12,) and in South Croatia (2). Low resistance was observed for these drugs because they are not easily accessible and relatively expensive in price compared to others. Thus, these drugs could be considered as alternative options in the empirical treatment of UTIs.

In conclusion, the isolation of bacterial uropathogens with a higher resistance rates for commonly used antimicrobials leaves the clinicians with very few options to choose drug used for empirical treatment of UTIs. Therefore, it is important to urge physician and other health worker in the field on the need of re-evaluation of empiric treatment of UTI.

As drug resistance among pathogens is an evolving process, routine surveillance and monitoring studies should be conducted to provide physicians with knowledge about the most effective empirical treatment of UTIs.'

\section{ACKNOWLEDGMENTS}

We are indebted to Jimma University for supporting this study.

\section{REFERENCES}

1. Ronald AR, Nicolle LE, Stamm E, et al. Urinary tract infection in adults: research priorities and strategies. Int $J$ Antimicrob Agents 2001; 17:343-348.

2. Baris 'ic' Z, Babic'-Erceg A, Borzic' El, et al. Urinary tract infections in South Croatia: aetiology and antimicrobial. Intl J Antimicrob Agents 2003; 22: S61-S64.

3. Gonzalez CM, Schaeffer AJ. Treatment of urinary tract infection: what's old, what's new, and what works. World J Urol. 1999; 17:372-382.

4. Stamm WE, Hooton TM. Management of urinary tract infections in adults. $N$ Engl $J$ Med. 1993; 329:1328-1334.

5. Wilson ML, Gaido L. Laboratory Diagnosis of Urinary Tract Infections in Adult Patients. Clin Infect Dis 2004; 38:1150-1158. 
6. Sefton AM. The impact of resistance on the management of urinary tract infections. Int $J$ Antimicrob Agents 2000; 16:489-491.

7. Bonadio M, Meini M, Spetaleri P, Gilgi C. Current microbiological and clinical aspects of urinary tract infections. Eur J Urol 2001; 40:439-445.

8. National Committee for Clinical Laboratory Standards. Performance standards for antimicrobial disc susceptibility tests. $7^{\text {th }}$ ed. Wayne, Pennsylvania, USA: NCCLS; 2000. M2-A7.

9. Grude N, Tveten Y, Kristiansen BE. Urinary tract infections in Norway: bacterial etiology and susceptibility, a retrospective study of clinical isolates. Clin Microbiol Infect 2001; 7:543-547.

10. Kripke C. Duration of therapy for women with uncomplicated UTI. Am Fam Physician 2005; 72:2219.

11. Sundqvist M, Kahlmeter G. 'Pre-emptive culturing' will improve the chance of getting it right' when empirical therapy of urinary tract infections fails. J Antimicrob Chemother 2009; 64:227-228.

12. Farajnia S, Alikhani MY, Ghotaslou R, Naghili B, Nakhlband A. Causative agents and antimicrobial susceptibilities of urinary tract infections in the northwest of Iran. Int J Infect Dis 2009; 13:140—144.

13. Clinical and Laboratory Standards Institute. Supplemental tables. Performance standards for antimicrobial susceptibility testing; fifteenth informational supplement. CLSI Publication M100-S15, M2-A8 and M7-A6. Pennsylvania: CLSI; 2005.

14. Kebira AN, Ochola P, and Khamadi SA. Isolation and antimicrobial susceptibility testing of Escherichia coli causing urinary tract infections. J. Appl. Biosci. 2009; 13201325 .

15. Water G, Harrison B, and Kunin G. Urinary tract infection. N. Eng Med. J 1996; 248-250.

16. Tessema B, Kassu A, Mulu A, Yismaw G. Predominant Isolates of Urinary Tract Pathogens and their susceptibility Patterns in Gonder Univesity Teaching Hospital, Northwest Ethiopia. Ethio Med J 2007; 45:6167.
17. Moges F, Genetu A. Antibiotic sensitivity of common bacterial pathogens in urinary tract infections at Gonder Hospital, Ethiopia. East Afr Med J. 2002, 79:140-142.

18. Biadglegne F, Abera B. Antimicrobial resistance of bacterial isolates from urinary tract infections at Felge Hiwot Referral Hospital, Ethiopia. Ethiop. J. Health Dev. 2009; 23:236-238.

19. Rakaa L, Mulliqi-Osmani G, Berisha L, et al. Etiology and susceptibility of urinary tract isolates in Kosova. Int $J$ Antimicrob agents 2004; 23S1S2-S5.

20. Assefa A, Asrat D, Woldeamanuel Y, G/Hiwot Y, Abdella A, Melesse T. Bacterial profile and drug susceptibility pattern of urinary tract infection in pregnant women at Tikur Anbessa Specialized Hospital Addis Ababa, Ethiopia. Ethiop Med J. 2008; 46:22735.

21. Ronald A. The etiology of urinary tract infection: Traditional and Emerging Pathogens. Am J Med 2002; 113 Suppl 1A: 14S-19S.

22. Dromigny JA, Nabeth P, Perrier Gros Claude JD. Distribution and susceptibility of bacterial urinary tract infections in Dakar, Senegal. Int $J$ Antimicrob Agents 2002; 20:339-47.

23. Bi XC, Zhang B, Ye YK et al . Pathogen incidence and antibiotic resistance patterns of catheter-associated urinary tract infection in children. J Chemother. 2009;21:661-665.

24. Khameneh ZR, Afshar AT. Antimicrobial susceptibility pattern of urinary tract pathogens. Saudi J Kidney Dis Transpl 2009; 20:251-253.

25. Chin BS, Kim MS, Han SH, et al. Risk factors of all-cause in-hospital mortality among Korean elderly bacteremic urinary tract infection (UTI) patients. Archives of Gerontology and Geriatrics 2011; 52:e50-e55.

26. Wolday D, Erge W. Increased incidence of resistance to antimicrobial by urinary pathogens isolated at Tikur Anbessa Hospital. Ethiop Med J 1997; 35:127-135.

27. Gebresselassie S. Asymptomatic bacteriuria in pregnancy: Epidemiology, clinical and microbiological approach. Ethiop Med J 1998; 185-95. 